Bangladesh J. Bot. 44(3): 443-449, 2015 (September)

\title{
EVALUATION OF FIELD PEA GERMPLASM AGAINST RUST DISEASE CAUSED BY UROMYCES VICIAE FABAE DE BARY IN GLASS HOUSE AND FIELD CONDITIONS
}

\author{
Deepak Singh ${ }^{*}$, Ashish Kumar Gupta ${ }^{1}$, Anil Kumar Singh ${ }^{2}$, \\ Ajoy Kumar Singh ${ }^{3}$ and Santosh Kumar ${ }^{4}$ \\ Department of Plant Pathology, College of Agriculture, G.B. Pant University of Agriculture \\ and Technology, Pantnagar, Uttarakhand- 263 145, India
}

Key words: Evaluation, Field pea germplasm, Rust disease, Apparent infection rate, Uromyces viciae fabae

\begin{abstract}
Seventy three germplasm of field pea were tested under glasshouse and field condition against rust disease caused by Uromyces viciae fabae (Pers.) de Bary. Among screened germplasms, 30 susceptible, 40 highly susceptible and 3 belonged to moderately resistance group. The susceptible germplasm showed leaf area with symptoms (LAS) ranged from 30 to $65 \%$ with area under disease progressive curve (AUDPC) values from 77.5 to 1290 and apparent infection rate from 0.0134 to 0.1698 and highly susceptible germplasm showed LAS ranged from 60 to $95 \%$ with AUDPC values ranged from 1075 to 2179. Apparent infection rate ranged from 0.0616 to 0.6950 while moderately resistance germplasm showed LAS ranged from 20 to $24 \%$ with AUDPC values ranged from 350 to 438 and apparent infection rate ranged from 0.1180 to 0.1198 in field as well as glasshouse conditions. The moderate resistance germplasm JPF 99025, KPMR 615 and KPMR 551showed lowest LAS, AUDPC value and apparent infection rate, hence, these germplasms could be used in breeding programme.
\end{abstract}

\section{Introduction}

The pea rust caused by Uromyces viciae fabae (Pers.) de Bary is one of the important pathogens of field pea (Pisum sativum L.) occurs in severe form in all the major growing areas of India (Kumar et al. 1994). It is worldwide distributed pathogen of pea and also reported to attack number of host species belonging to family leguminaceae viz., faba bean (Vicia faba L.), lentil (Lens culinaris Medic) and sweet pea (Lathyrus sativus L.) (Chung et al. 2004, Kushwaha et al. 2006, Shroff and Chand 2010). The disease can cause substantial yield losses particularly in warm weather conditions which ranges from 56.8 to 100 per cent (Upadhyay and Singh 1994, Kushwaha et al. 2010) and significant damage in terms of quality and quantity in pea, faba bean and lentil in India (Sharma 1998, Beniwal et al. 1993). It is an autoecious and microcyclic fungus and incidence of disease at early growth stages may result in complete failure of the crop. The genetics of rust resistance in pea is still unclear, and workers have reported a single dominant gene (Tyagi and Srivastava 1999), a single oligogene (Vijayalakshmi et al. 2005) showing partial dominance along with some minor gene or involvement of one to two major genes (Singh and Ram 2001). Several source of incomplete resistance against $U$. viciae fabae have been reported (Xue and Warkentin 2002, Vijayalakshmi et al. 2005, Chand et al. 2006, Barilli et al. 2009). In India all the

\footnotetext{
*Author for correspondence: <deepaksingh_pp@yahoo.com>. Present address: SMS (Plant Protection), Krishi Vigyan Kendra Sitamarhi-843 320, Bihar, India ${ }^{1}$ Plant Pathology, IARI Regional Station, Pusa, Samastipur, Bihar, 848125, India. ${ }^{2}$ Agronomy, ICAR Research Complex for Eastern Region, Patna, Bihar, 800 014, India. ${ }^{3}$ Zonal Project Director, Zonal Project Directorate, Zone-2, Kolkatta, West Bengal, 700097, India. ${ }^{4}$ Plant Pathology, Bihar Agriculture University, Sabour, Bhagalpur, Bihar, 813210,India
} 
pea germplasm/cultivars have been tested and reported as susceptible, while no immune or hypersensitive or resistant cultivar was recorded. However, race specific vertical resistance against Uromyces viciae fabae has also been reported (Singh and Sokhi 1980 and 1981, Sohi et al. 1974, Sokhi et al. 1984).

Cultivation of resistant varieties is one of the major options to stabilize the productivity of field pea crop. The varieties of field pea released in India for general cultivation are known to be susceptible against rust. Therefore, enhancement of rust resistance in field pea cultivars is a major challenge, which needs to be addressed on priority. Present investigation was undertaken to characterize leaf area with symptoms (LAS) values, area under disease progress curve (AUDPC) and apparent infection rate (r) in promising germplasm of field pea and to assess its importance as selection criterion in field pea rust resistance improvement programme. These parameters are being used to compare the relative susceptibility or resistance of varieties or lines. The generated information will allow the growers to increase the adaptation of multiple disease resistant cultivars.

\section{Materials and Methods}

The experiment was conducted under glasshouse as well as in field conditions at Crop Research Centre, G. B. Pant University of Agriculture and Technology, Pantnagar. Seventy five germplasm included in advanced varietal trail-1, advanced varietal trail-2 and initial varietal trails of All India Coordinated Research Project on MULLaRP, evaluated under field and greenhouse conditions for LAS, AUDPC and apparent infection rate in 2003 - 2004 and 2004 - 2005.

Field experiment was planned in randomized block design with 4 replications and, standard agronomic practices were followed to raise healthy crop. Each germplasm was sown in $4 \mathrm{~m}$ row length with $30 \times 15 \mathrm{~cm}$ line to line and plant to plant spacing, respectively. A highly susceptible variety 'Aparana' was sown after every 3 rows as spreader infector row. Pathogen inoculum was multiplied on susceptible variety 'Aparana' sown 30 days before planting of main experiment by inoculating aeciospores derived from single pustules. The rust infected plants were uprooted, incision their roots with knife and soaked in distilled water to prepare a suspension of $10^{5}$ spore/ml. Standard inoculation technique (Chand et al. 2004) was followed and inoculation was done by spraying the spore suspension at the pre flowering stage of the plants (i.e., 55 - 60 days after sowing) during evening hours. Immediately after inoculation, field was lightly irrigated and two additional irrigations were given at 10 days intervals to maintain proper moisture level. The disease severity for each germplasm was visually estimated on a 0 - 9 scale (Sokhi et al. 1984). Ten plants were randomly selected tagged from each row used for recording disease severity and other released parameters. First observation was recorded when disease severity was around 50\% on the susceptible check (Aparana) and accordingly, two more observations were taken at 4 days interval to calculate AUDPC (Kushwaha 2007).

The 73 germplasms were sown at the same time in plastic pots $(30 \mathrm{~cm}$ diameter) filled with normal soil amended with farm yard manure to support luxuriant plants growth. Five plants were grown per pot and three pots of each germplasm treated as a single replication. The replicated pots of each germplasm were arranged in a randomized block design in the experiment. All pots were kept in growth chamber at $25^{\circ} \mathrm{C}$ in day and $20^{\circ} \mathrm{C}$ in night temperature with a $16 \mathrm{hrs}$ photoperiod and watered twice in the week to maintain the adequate moisture level. Plants were inoculated at most susceptible stage i.e., four to six node stage, which occurred at 15 to 20 days after planting (Xue and Warkentin 2002).

The suspension of aeciospores/urediospores of $U$. viciae fabae was prepared by mixing the spore with light mineral oil (Soltrol 170) and adjusted to $10^{5}$ spore/ml using a haemocytometer. 
The spore suspension was applied at $1 \mathrm{ml} / \mathrm{plant}$ through atomizer. After natural drying, the plants were placed in a mist chamber with 100 per cent relative humidity at $20^{\circ} \mathrm{C}$ in dark for $24 \mathrm{hrs}$ and then returned to glasshouse for pathogenesis (Chand et al. 2004). Six pots of "Aparana" sprayed only with mineral oil were included as checks (control) against extraneous airborne inoculum. Under glasshouse condition, 3 pots of individual genotypes were considered for disease severity. Observation on disease severity was recorded on individual plants 10,12,14 days intervals from the first scoring done when disease appeared in pots plant.

Leaf area with symptoms was used to quantify the disease severity of field pea germplasm to rust. The LAS was assessed on two leaf disks $(15 \mathrm{~mm}$ diameter) taken from each of the 4th and 6th nodes of each plant 20 days after inoculation. Disease severity score was then converted to LAS values using the equation LAS $=\sum$ (medium value in a category $\times$ number of leaf disk in the category) /Total no of leaf disks. Per cent LAS was used to quantify the disease severity of the field pea germplasm against rust. Data were analyzed by analysis of variance and germplasm means were separated by the least significant difference (LSD) test at a probability level of 0.05 . The area under disease progress curve (AUDPC) values was calculated with the help of computer software developed at CIMMYT as $\sum\left[\left\{\left(\mathrm{Yi}+\mathrm{Y}_{(\mathrm{i}+1)} 2\right\} \times\left(\mathrm{t}_{(\mathrm{i}+1)}-\mathrm{t}_{\mathrm{i}}\right)\right\}\right.$ where $\mathrm{Y}=$ disease severity at time $t_{i}$ and $\left(t_{(i+1)}-t_{i}\right)=$ number of days between 2 disease scores and apparent infection rate $(r)$ values was calculated by Vander Plank (1963) for field rust as $r$ per days $=2.3 / T_{1}-T_{2} \log X 2 / \mathrm{X} 1$ where $\mathrm{r}=$ apparent rate of infection/spread, $\mathrm{X}_{1}=$ Per cent disease severity at time $\mathrm{T}_{1}, \mathrm{X}_{2}=$ Per cent disease severity at time $\mathrm{T} 2, \mathrm{~T}_{2}-\mathrm{T}_{1}=$ Time interval in days between two observation. On the basis of LAS (\%) values obtained in experimental result, the screened germplasm characterized in moderately resistant, susceptible and highly susceptible and, finally tabulated separately.

\section{Results and Discussion}

Field and glasshouse studies indicated that none of the tested field pea germplasm was found immune to $U$. viciae fabae. Among 73 germplasms tested, only 30 showed susceptible reaction under glasshouse and field condition. The susceptible germplasm HUP 2 showed minimum AUDPC value 77.5 in field condition and 85.1 in glasshouse condition, however, the maximum AUDPC value 1285.0 in field condition and 1290.0 in glasshouse condition was observed in KMPR 171 followed by KPMR 569 susceptible germplasm. The apparent infection rate in susceptible germplasm was recorded from 0.0134 to 0.1668 per cent in field condition and 0.0158 to 0.1698 per cent in glasshouse condition (Table 1).

Only 40 germplasms showed highly susceptible reaction in both condition, their LAS ranged from 60 to 90 per cent in field condition and 61 to 95 per cent in glasshouse condition. The germplasm KPMR 526 showed minimum AUDPC value i.e., 1075 in field condition and 1079 in glasshouse condition, While the maximum AUDPC value 2175.0 in field condition and 2179.0 in glasshouse condition was observed in DDR 49, which was considered as highly susceptible germplasm. The apparent infection rate in highly susceptible germplasm ranged from 0.0616 to 0.6922 per cent in field condition and 0.0615 to 0.6950 per cent in glasshouse condition (Table 2).

The disease resistance in commercial field pea varieties against rust has not previously been reported in India. Pal et al. (1980) reported three accessions of Pisum species resistant to rust under field condition in India, however these resistant accessions were not considered suitable for commercial cultivation. All the tested germplasms under field as well as glasshouse condition showed compatible reaction to rust. Out of 73 germplasms screened, not a single germplasm showed complete resistance, however three germplasm JPF 99025, KPMR 615 and KPMR 551 showed moderately resistance reaction with minimum LAS ranged in both condition 20 to 24 per cent, AUDPC ranged between 350 and 438.0 and apparent infection rate from 0.1180 to 0.1198 
(Table 3) than highly susceptible and susceptible germplasm. Low LAS, AUDPC and apparent infection rate values associated with high level of resistance (Chand et al. 2004 and 2006, Upadhyay and Singh 1994, Xue and Warkentin 2002, Singh et al. 2012). LAS, AUDPC value and apparent infection rate under glass house condition and field condition almost similar, however slightly higher values of tested parameters are reported in glasshouse condition that might be due

Table 1. Leaf area with symptoms, area under disease progress curve values, apparent infection rate of susceptible germplasm of field pea screened during 2003-04 and 2004-2005.

\begin{tabular}{|c|c|c|c|c|c|c|c|}
\hline \multirow{2}{*}{$\begin{array}{l}\text { Sl. } \\
\text { No. }\end{array}$} & \multirow{2}{*}{$\begin{array}{l}\text { Germplasm } \\
\text { (Name) }\end{array}$} & \multicolumn{2}{|r|}{ LAS $(\%)$} & \multicolumn{2}{|c|}{ AUDPC Values } & \multicolumn{2}{|c|}{ Apparent infection rate } \\
\hline & & In field & In glasshouse & In field & In glasshouse & In field & In glasshouse \\
\hline 1 & MPMR-284 & 40.0 & 43.0 & 820.0 & 824.0 & 0.1206 & 0.1218 \\
\hline 2 & KPMR 65 & 40.0 & 41.0 & 732.5 & 738.1 & 0.1136 & 0.1143 \\
\hline 3 & KPMR 420 & 50.0 & 52.0 & 937.5 & 942.8 & 0.1318 & 0.1421 \\
\hline 4 & KPMR 171 & 50.0 & 48.0 & 1285.0 & 1290.0 & 0.0643 & 0.0648 \\
\hline 5 & KPMR 427 & 48.0 & 50.0 & 1050.0 & 1054.0 & 0.1053 & 0.1083 \\
\hline 6 & JP28 & 50.0 & 50.0 & 1050.0 & 1055.0 & 0.1053 & 0.1083 \\
\hline 7 & DMR 35 & 45.0 & 50.0 & 1165.0 & 1169.0 & 0.1039 & 0.1042 \\
\hline 8 & HUP 6 & 45.0 & 49.0 & 927.5 & 935.8 & 0.1318 & 0.1365 \\
\hline 9 & HUP 2 & 40.0 & 45.0 & 77.5 & 85.1 & 0.1010 & 0.1015 \\
\hline 10 & ET 45191 & 30.0 & 31.0 & 600.0 & 619.0 & 0.1026 & 0.1136 \\
\hline 11 & NIC20395 & 40.0 & 42.0 & 930.0 & 931.0 & 0.0745 & 0.0813 \\
\hline 12 & KSP 26 & 50.0 & 50.0 & 1165.0 & 1170.0 & 0.1039 & 0.1045 \\
\hline 13 & KPMR 27 & 30.0 & 32.0 & 650.0 & 653.0 & 0.1206 & 0.1283 \\
\hline 14 & KPMR 485 & 40.0 & 48.0 & 860.0 & 890.0 & 0.1206 & 0.1290 \\
\hline 15 & KPMR 226 & 40.0 & 45.0 & 827.5 & 838.0 & 0.1010 & 0.1015 \\
\hline 16 & KPMR 5 & 30.0 & 35.0 & 652.5 & 657.0 & 0.1114 & 0.1118 \\
\hline 17 & KPMR 46 & 30.0 & 31.0 & 630.0 & 638.0 & 0.1287 & 0.1290 \\
\hline 18 & DMR 44 & 50.0 & 50.0 & 1020.0 & 1021.0 & 0.1668 & 0.1698 \\
\hline 19 & HFP 92-12 & 45.0 & 50.0 & 1152.5 & 1156.0 & 0.0134 & 0.0158 \\
\hline 20 & HUDP 19 & 50.0 & 50.0 & 1065.0 & 1067.0 & 0.1053 & 0.1083 \\
\hline 21 & HUDP 17 & 40.0 & 45.0 & 750.0 & 756.0 & 0.1361 & 0.1371 \\
\hline 22 & JPF 99-31 & 30.0 & 32.0 & 577.5 & 580.0 & 0.0191 & 0.0195 \\
\hline 23 & JPF 99-26 & 43.0 & 50.0 & 1145.0 & 1148.0 & 0.1053 & 0.1063 \\
\hline 24 & DDR 60 & 50.0 & 50.0 & 1050.0 & 1058.0 & 0.1053 & 0.1083 \\
\hline 25 & DDR 23 & 60.0 & 65.0 & 1087.0 & 1090.0 & 0.0952 & 0.0960 \\
\hline 26 & DDR 27 & 45.0 & 50.0 & 937.0 & 940.0 & 0.1318 & 0.1352 \\
\hline 27 & KPMR 619 & 40.0 & 42.0 & 827.5 & 830.0 & 0.1531 & 0.1561 \\
\hline 28 & JPF 98-16 & 40.0 & 45.0 & 930.0 & 935.0 & 0.0745 & 0.0789 \\
\hline 29 & LEP 283 & 50.0 & 50.0 & 1140.0 & 1145.0 & 0.1053 & 0.1063 \\
\hline 30 & KPMR 569 & 50.0 & 50.0 & 1225.0 & 1227.0 & 0.0650 & 0.0658 \\
\hline \multicolumn{2}{|c|}{$\operatorname{LSD}(p=0.05 \%)$} & 12.76 & 14.67 & 50.78 & 56.89 & 0.301 & 0.350 \\
\hline
\end{tabular}

*Average of two years data. 
Table 2. Leaf area with symptoms, area under disease progress curve values, apparent infection rate of highly susceptible germplasm of field pea screened in 2003-04 and 2004-2005.

\begin{tabular}{|c|c|c|c|c|c|c|c|}
\hline \multirow{2}{*}{$\begin{array}{l}\text { Sl. } \\
\text { No. }\end{array}$} & \multirow{2}{*}{$\begin{array}{l}\text { Germplasm } \\
\text { (Name) }\end{array}$} & \multicolumn{2}{|c|}{ LAS (\%) } & \multicolumn{2}{|c|}{ AUDPC Values } & \multicolumn{2}{|c|}{ Apparent infection rate } \\
\hline & & In field & In glasshouse & In field & $\overline{\text { In glasshouse }}$ & In field & In glasshouse \\
\hline 1 & KPMR 593 & 60.0 & 65.0 & 1350.0 & 1352.0 & 0.0951 & 0.0960 \\
\hline 2 & KPMR 65-1 & 70.0 & 73.0 & 1617.50 & 1620.50 & 0.1114 & 0.1123 \\
\hline 3 & KPMR 212 & 70.0 & 71.0 & 1512.50 & 1537.50 & 0.1114 & 0.1118 \\
\hline 4 & $6238 \mathrm{R}$ & 60.0 & 61.0 & 1477.50 & 1487.61 & 0.0778 & 0.0797 \\
\hline 5 & JP21 & 60.0 & 62.0 & 1500.0 & 1525.00 & 0.0616 & 0.0615 \\
\hline 6 & KSP 9 & 60.0 & 65.0 & 1350.0 & 1380.0 & 0.0951 & 0.0983 \\
\hline 7 & JM6 & 70.0 & 75.0 & 1425.0 & 1435.0 & 0.1697 & 0.1705 \\
\hline 8 & DPFD 8 & 80.0 & 83.0 & 1682.5 & 1690.0 & 0.1523 & 0.1585 \\
\hline 9 & JP 9 & 70.0 & 73.0 & 1520.0 & 1525.0 & 0.0643 & 0.0663 \\
\hline 10 & JP181 & 60.0 & 68.0 & 1300.0 & 1345.0 & 0.1361 & 0.1387 \\
\hline 11 & HFP 94-22 & 60.0 & 63.0 & 1175.0 & 1180.0 & 0.1361 & 0.1391 \\
\hline 12 & DMR 36 & 60.0 & 65.0 & 1200.0 & 1235.0 & 0.1361 & 0.1381 \\
\hline 13 & DDR 44 & 70.0 & 78.0 & 1250.0 & 1268.0 & 0.1647 & 0.1785 \\
\hline 14 & DDR 50 & 60.0 & 65.0 & 1212.5 & 1225.1 & 0.1143 & 0.1183 \\
\hline 15 & PM 5 & 60.0 & 63.0 & 1325.0 & 1340.1 & 0.1361 & 0.1371 \\
\hline 16 & JP 169 & 60.0 & 62.0 & 1237.5 & 1240.01 & 0.1143 & 0.1185 \\
\hline 17 & EC292161 & 60.0 & 61.0 & 1175.0 & 1179.0 & 0.1361 & 0.1371 \\
\hline 18 & HUP 2 & 70.0 & 78.0 & 1425.0 & 1430.0 & 0.0643 & 0.0683 \\
\hline 19 & HFP 8909 & 80.0 & 83.0 & 1655.0 & 1673.0 & 0.1697 & 0.1792 \\
\hline 20 & NBP 1 & 70.0 & 76.0 & 1500.0 & 1520.0 & 0.1287 & 0.1290 \\
\hline 21 & LEP 323 & 70.0 & 78.0 & 1278.50 & 1290.0 & 0.1478 & 0.1490 \\
\hline 22 & DDR 56 & 60.0 & 65.0 & 1380.0 & 1385.0 & 0.1316 & 0.1318 \\
\hline 23 & DDR 57 & 90.0 & 92.0 & 1650.0 & 1658.0 & 0.1977 & 0.2010 \\
\hline 24 & DDR 59 & 80.0 & 80.5 & 1665.0 & 1665.80 & 0.1361 & 0.1362 \\
\hline 25 & KPMR 602 & 70.0 & 73.0 & 1537.5 & 1540.0 & 0.1114 & 0.1116 \\
\hline 26 & KPMR 606 & 90.0 & 91.0 & 1825.0 & 1830.0 & 0.1978 & 0.1980 \\
\hline 27 & HBP 2 & 70.0 & 73.0 & 1537.0 & 1537.5 & 0.1114 & 0.1118 \\
\hline 28 & KPMR 603 & 90.0 & 91.0 & 2062.5 & 2064.0 & 0.1822 & 0.1911 \\
\hline 29 & JPF 98-1 & 70.0 & 71.0 & 1425.0 & 1428.0 & 0.1287 & 0.1290 \\
\hline 30 & DDR 55 & 90.0 & 92.0 & 1912.0 & 1930.0 & 0.1822 & 0.1835 \\
\hline 31 & IPF 98-9 & 70.0 & 76.0 & 1690.0 & 1695.0 & 0.0951 & 0.0981 \\
\hline 32 & DDR 40 & 80.0 & 82.0 & 1715.0 & 1723.0 & 0.1356 & 0.1386 \\
\hline 33 & DDR 39 & 70.0 & 75.0 & 1400.0 & 1420.00 & 0.1112 & 0.1163 \\
\hline 34 & DMR 42 & 90.0 & 92.0 & 2150.0 & 2160.0 & 0.1669 & 0.1735 \\
\hline 35 & DDR 50 & 80.0 & 85.0 & 1802.5 & 1807.1 & 0.1200 & 0.1210 \\
\hline 36 & DDR 49 & 90.0 & 92.0 & 2175.0 & 2179.0 & 0.1669 & 0.1679 \\
\hline 37 & DDR 54 & 90.0 & 95.0 & 2165.0 & 2170.0 & 0.1669 & 0.1680 \\
\hline 38 & KPMR 526 & 70.0 & 76.0 & 1075.0 & 1079.0 & 0.6922 & 0.6950 \\
\hline 39 & HUDP 16 & 70.0 & 72.0 & 1320.0 & 1323.0 & 0.1270 & 0.1285 \\
\hline 40 & KPMR 583 & 70.0 & 71.0 & 1552.0 & 1554.0 & 0.1112 & 0.1115 \\
\hline \multicolumn{2}{|c|}{$\operatorname{LSD}(p=0.05 \%)$} & 14.70 & 16.87 & 58.80 & 60.09 & 0.531 & 0.550 \\
\hline
\end{tabular}

*Average of two years data. 
Table 3. Leaf area with symptoms, area under disease progress curve values, apparent infection rate of moderately resistance germplasm of field pea screened in 2003-04 and 2004-2005.

\begin{tabular}{|c|c|c|c|c|c|c|c|}
\hline \multirow{2}{*}{$\begin{array}{l}\text { Sl. } \\
\text { No. }\end{array}$} & \multirow{2}{*}{$\begin{array}{l}\text { Germplasm } \\
\text { (Name) }\end{array}$} & \multicolumn{2}{|c|}{ LAS (\%) } & \multicolumn{2}{|c|}{ AUDPC Values } & \multicolumn{2}{|c|}{ Apparent infection rate } \\
\hline & & In field & $\begin{array}{c}\text { In } \\
\text { glasshouse }\end{array}$ & In field & $\begin{array}{c}\text { In } \\
\text { glasshouse }\end{array}$ & In field & $\begin{array}{c}\text { In } \\
\text { glasshouse }\end{array}$ \\
\hline 1 & JPF 99025 & 22.0 & 24.0 & 432.5 & 438.0 & 0.1184 & 0.1198 \\
\hline 2 & KPMR 615 & 20.0 & 22.0 & 410.0 & 412.0 & 0.1904 & 0.1908 \\
\hline 3 & KPMR 551 & 20.0 & 20.0 & 350.0 & 351.0 & 0.1180 & 0.1181 \\
\hline \multicolumn{2}{|c|}{$\operatorname{LSD}(p=0.05 \%)$} & 10.70 & 9.87 & 41.98 & 43.78 & 0.031 & 0.068 \\
\hline
\end{tabular}

*Average of two years data.

to more congenial environments for the disease development (Chand et al. 2004). The higher disease severity and AUDPC was recorded in glasshouse. Negussie et al. (2005) also observed that the high heritability of disease severity and AUDPC suggested that selection of pea rust resistance can be made under polyhouse conditions using either disease severity or AUDPC as disease reaction indicator. Thus it is proposed that germplasm lines should be screened under the glasshouse also to identify reliable resistant plants or genotypes during breeding for resistance. Resistant varieties are most economical and ecofriendly way to manage the diseases. The generated information will allow the growers to increase the adaptation of multiple disease resistant cultivars. On the basis of these findings it can be proposed that germplasm JPF 99025, KPMR 615 and KPMR 551 identified as moderately resistant lines can be utilized as donor parent for further breeding programme of disease resistance field pea and will also be helpful in testing of breeding material and selection of best fieldpea genotype for further breeding work.

\section{Acknowledgement}

The authors are thankful to Indian Council of Agricultural Research, New Delhi for financial assistance in the form of adhoc scheme.

\section{References}

Barilli E, Sillero JC, Fernandez-Aparicio M and Rubiales D 2009. Identification of resistance to Uromyces pisi (Pers.) Wint. in Pisum spp. germplasm. Field Crop Res. 114: 198-203.

Beniwal SPS, Bayaa B, Weigand S, Makkouk K and Saxena MC 1993. Field guide to lentil disease and insect pests. International Centre for Agricultural Research in Dry Area. Aleppo, Syria. p. 106.

Chand R, Srivastava CP, Singh BD and Sarode SB 2006. Identification and characterization of slow rusting components in pea (Pisum sativum L.). Gen. Res. and Crop Evol. 53: 219-224.

Chand R, Srivastava CP and Kushwaha C 2004. Screening technique for pea (Pisum sativum L.) genotypes against rust disease (Uromyces fabae pers de Bary). Indian J. Agric. Sci. 74: 166-167.

Chung WH, Tsukiboshi TOY and Kakishma M 2004. Phylogenic analyses of Uromyces viciae fabae and its varieties on Vicia, Lathyrus and Pisum in Japan. Mycosci. 45: 1-8.

Kumar Anil TB, Rangaswamy KT and Ravi KT 1994. Assessment of tall field pea genotypes for slow rusting resistance. Leg. Res. 17: 79-82.

Kushwaha C, Chand R, Srivastava CP 2006. Role of aeciospores in outbreak of pea (Pisvum sativum) rust (Uromyces fabae). European J. Plant Pathol. 115: 323-330. 
Kushwaha C, Chand R, Srivastava CP, Singh AK, Rai R and Singh BD 2010. Importance of aecial cups/pustule for selection for slow rusting in pea (Pisum sativum) against Uromyces fabae. Indian $\mathrm{J}$. Agric. Sci. 80(10): 933-936.

Kushwaha C, Srivastava CP, Chand R and Singh BD 2007. Identification and evaluation of critical time for assessment of slow rusting in pea against Uromyces fabae. Field Crop Res. 103: 1-4.

Negussie T, Petorius ZA and Bender CM 2005. Components of rust resistance in lentil. Euphytica 142 : 55-64.

Pal A, Brahmappa B, Rawal RD and Ullasa BA 1980. Field resistance of pea germplasm to powdery mildew (Erysiphe polygoni) and rust (Uromyces fabae). Plant Dis. 64: 1085-1086.

Sharma AK 1998. Epidemiology and management of ruts disease of french bean. Veg. Sci. 25(1): 85-88.

Sokhi SS,Singh SJ and Munshi GD 1984.Parameters of rating pea varieties/lines against rust. Indian Phytopath. 37: 252-255.

Shroff S and Chand R 2010. Preinfection biology of aeciospores of Uromyces fabae. Int. J. Curr. Trends Sci. Tech. 1(2): 1-10.

Singh AK, Rai R, Srivastava CP, Singh BD, Kushwaha C and Chand R 2012. A quantitative analysis of rust (Uromyces fabae) resistance in pea (Pisum sativum) using RILs. Indian J. of Agric. Sci. 82(2): 190-192.

Singh R and Ram H 2001. Inheritance of powdery mildew and rust resistance in pea. Ann. of Biol. 15: 13-16.

Singh SJ and Sokhi SS 1980. Pathogenic variability in Uromyces viciae fabae (Pers) de Bary. Pl. Dis. 64: 671-672.

Singh SJ and Sokhi SS 1981. Evaluation of pea cultivars to Uromyces viciae fabae. Indian Phytopath. $34: 85$.

Sohi HS, Sokhi SS and Rawal RD 1974. Varietal reaction of pea to powdery mildew (Erysiphe polygoni) and rust (Uromyces fabae). Mysore J. Agri. Sci. 8: 529-532.

Tyagi M K and Srivastava CP 1999. Inheritance of powdery mildew and rust resistance in pea. Ann. Bio. 15: 13-16.

Upadhyay AL and Singh VK 1994. Performance of pea varieties/ lines against powdery mildew and rust. Indian J. Pulses Res. 7: 92-93.

Vander Plank JE 1963. Plant Diseases: Epidemic and control. Academic Press, New York. pp. 349.

Vijayalakshmi S, Yadav K, Kushwaha C, Sarode SB, Srivastava CP, Chand R and Singh BD 2005. Identification of RAPD markers linked to rust (Uromyces fabae) resistance gene in pea (Pisum sativum). Euphytica 144: 265-274.

Xue AG and Warkentin TD 2002. Reaction of field pea varieties to three isolates of Uromyces fabae. Canadian J. Plant Sci. 82(1): 253-255.

(Manuscript received on 10 January, 2013; revised on 3 March, 2014) 